\title{
Exploring talent management execution in the Ministry of Justice in the Namibian public sector
}

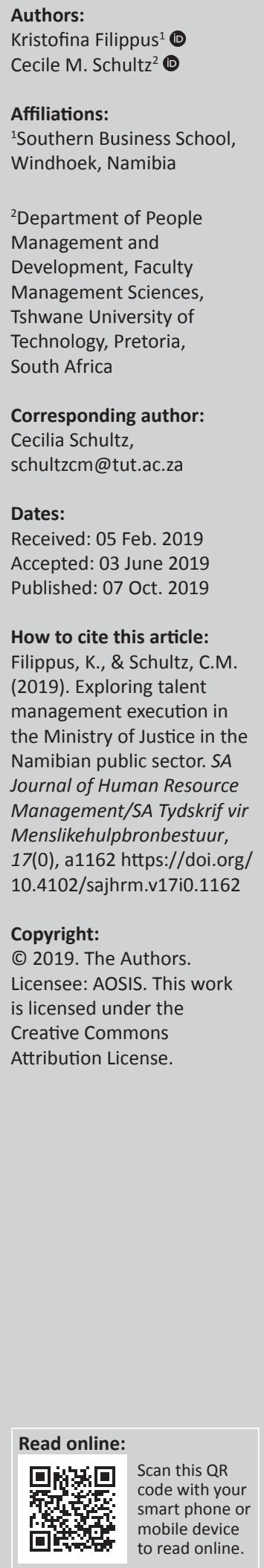

Orientation: The Ministry of Justice in the government of the Republic of Namibia, which is tasked to implement an effective judicial system in the country, is one of the public sector institutions rocked by a shortage of critical skills.

Research purpose: The aim of this study was to scrutinise the execution of talent management practices in the Ministry of Justice in the Namibian public sector by investigating the talent management execution levels, identifying the distractors and enablers that form part of the talent management practices and developing a conceptual framework of talent management execution.

Motivation for the study: The war for talent is evident in the Ministry of Justice in the Namibian public sector, and limited research exists regarding the execution of talent management in this organisation.

Research approach/design and method: The research was based on an exploratory research design and a qualitative approach was used. Purposive sampling was utilised and semistructured interviews were conducted. The data were analysed by means of qualitative content analysis.

Main findings: Talent management was executed on three levels: human resource execution, operational execution and strategic execution. Specific distractors and enablers were identified and formed part of the talent management practices.

Practical/managerial implications: To execute talent management properly, managers and human resource managers should attend to the identified talent management distractors and enablers.

Contribution/value-add: Talent management execution levels and the relating distractors and enablers were identified. A conceptual framework of talent management execution in the Ministry of Justice in the Namibian public sector was developed.

Keywords: Human Resource, HR; Execution; Namibian Public Sector; Operational Execution; Strategic Execution; Talent Management.

\section{Introduction}

Business leaders who execute the best talent management processes are more prepared than their competitors to compete in the global economy and capitalise quickly on new opportunities. Talent management practices are focal tools for attracting top talent to key roles, but are recognised as a great global challenge to organisations (Johnson, 2015). An aspect of talent management that needs consideration is the levels of responsibility within a particular organisational context (Tansley, 2011). Talent management ought to be executed by human resource (HR) (Maheshwari, Gunesh, Lodorfos, \& Konstantopoulou, 2017). Operational execution (King, 2017) and strategic execution (Hughes \& Rog, 2008) of talent management are imperative. A paradigm shift from traditional HRs to strategic talent management is needed and this may lead to changes in the organisational business practices and procedures (Van Zyl, Mathafena, \& Ras, 2017). 'Talent is left to sink or swim as they are progressed into new roles, projects or secondments without adequate support or structured development' (Ross, 2013, p. 12). Distractors and enablers should form part of the talent management practices.

\section{Research purpose}

The Ministry of Justice in the government is tasked to implement an effective judicial system in the country, and is one of the public sector institutions affected by the impact of a shortage of 
critical skills (Ministry of Justice, 2017). The war for talent is evident in the Ministry of Justice in the Namibian public sector, and limited research exists regarding the investigation of the execution of talent management in this organisation (Nakuta \& Chipepera, 2010). There is also no knowledge of what the distractors and enablers are in relation to talent management execution in this organisation. The aim of this study was therefore to address these research gaps by uncovering the execution of talent management in the Ministry of Justice in the Namibian public sector. In the light of the above, the execution of talent management in the Ministry of Justice in the Namibian public sector was explored by:

- investigating the talent management execution levels

- identifying the distractors and enablers that form part of the talent management practices

- developing a conceptual framework of talent management execution.

\section{Literature review}

\section{Talent management overview}

In earlier times, organisations were exposed to a limited set of HR practices. Johnson (2015) posits that talent management is about the early identification of key role players and articulation of duties, leading to ownership and clear accountability to ensure organisational success. Poisat, Mey and Sharp (2018) maintain that talent management concerns creating a high-performance work culture at all organisational levels, resulting in all company employees being well informed of competitive advantage. Lewis and Heckman (2006, p. 139), who conducted an extensive review of the talent management literature in both professional and academic publications, found that talent management comprised 'a collection of typical human resource department practices ... such as recruiting, selection, development and career and succession management.' Lewis and Heckman's (2006) view of talent management is considered more or less synonymous with HR or workforce planning. The third and final perspective on talent management of Lewis and Heckman (2006) focuses on sourcing, developing and rewarding employee talent.

Talent management serves as a supportive tool to improve staff members' performance to ensure the organisation's success in achieving its intended goal (Barkhuizen, Schutte, \& Smith, 2015). Ogbari, Onasanya, Ogunnaike and Kehinde (2018) are of the opinion that one of the main components of talent management is continuously training personnel to maintain the required level of performance. Employees who receive personal development and are involved in the talent management programme are expected to be more innovative and to contribute exceptionally to the success of the organisation (Ogbari et al., 2018).

\section{Human resource, operational and strategic levels of talent management}

According to Bothma (2015), talent management is a strategy designed to enhance an organisation's current processes and practices, and to deliver corporate and HR management (HRM) strategies. Bothma (2015) further opines that the greatest HR challenge is to obtain the required skills to link talent management practices and the broader HR system. Human resource needs to plan and execute talent management (Maheshwari et al., 2017).

Operational level is another level of talent management execution (King, 2017). King (2017) further mentions that organisational systems and practices across the diverse range of today's workspaces and the strength of an organisation's talent system may practically be expected to become a noticeable element of an organisation's approach to attract, develop and retain the talent it requires for its business purpose.

Strategic talent management refers to the long-term or future talent needs of an organisation (Hughes \& Rog, 2008). A paradigm shift from traditional HRs to strategic talent management is needed and this may lead to changes in the organisational business practices and procedures (Van Zyl et al., 2017). To ensure proper execution of talent management at HR, operational and strategic levels, distractors and enablers of talent management should be identified.

\section{Talent management distractors}

Distractors pertain to issues that do not enhance talent management execution and can also be seen as challenges. Li, Hedayati-Mehdiabadi, Choi, Wu and Bell (2018) state several challenges regarding talent management process, including challenges of attracting and retaining talent, tension between subsidiaries and headquarters, tension between high potentials and non-high potentials and tension between generations. Van Hoek (2016) states that many organisations are negatively challenged by the war for talent with regard to imperative talent management factors such as work motivation, attraction, development, work value and recruitment. Organisations fail to successfully implement talent management because of lack of understanding of how to acquire, develop and retain high-potential talent in this competitive world (Pannell, 2015). Pannell (2015) further maintains that companies fail to accept that pay is an astounding defence for winning the talent war, especially with regard to the retention and attraction of real talent. Craig (2017) is of the opinion that most organisations fail to properly employ talent management practices because they miss the point of how most of the power has now shifted from the employer to the talented employee.

Another distractor is the lack of retention programmes. As a result of a lack of retention programmes, high performers keep leaving organisations. According to Riccardi (2015, p. 33), organisations struggle with talent attraction strategies because of lack of consideration for candidate experience, caused by the emerging technology of online applications. Talent attraction strategies can therefore be a distractor if not properly managed. Riccardi (2015) also maintains that online applications make it difficult for organisations to choose 
candidates with good and relevant experience because of thousands of applications being received. In recently conducted research, Sirin (2018) found that talent acquisition was one of the biggest challenges with a negative impact on organisations. According to Ogbari et al. (2018), the comprehensive solution to talent management challenges is composed of strategic job requirements, job grading, performance management, recruitment criteria and succession planning.

\section{Talent management enablers}

Enablers refer to issues that enhance talent management execution to win the war for talent. Krasavin and De Swardt (2016) refer to talent management as the war for talent. Organisations that keep strategising their day-to-day business operation in accordance with talent management can win the war for talent and survive in a competitive world (Dinnen, 2017). Ulrich (2016) found that organisations can win the war for talent only if they practise talent management that is focused on the organisational future performance to attract investors. Some of the essentials that organisations need to act on to win this war are creating a winning employee value proposition, moving beyond the recruiting hype, using job experience, coaching and mentoring, investing in strong performers, grooming better performers and acting decisively on poor performers (Krasavin \& De Swardt, 2016).

Hosking (2017) recommends that one of the key enablers of talent management is talent acquisition. Hosking (2017) considers talent acquisition as a fundamental tool to appoint the right people at the right time. Organisations that can attract, retain and develop employees will have a distinct edge in competitive environments (Maheshwari et al., 2017). The talent management framework of Phillips and Roper (2009) consists of five key elements, namely, attracting, selecting, engaging, developing and retaining employees. These elements should be enablers to ensure that talent management is executed effectively:

Talent management challenges can be addressed by aligning and integrating people management practices with those of the organisation, through developing the organizational talent management framework, in order to achieve strategic execution and operational excellence. (Van Zyl et al., 2017, p. 18)

Lee (2018) is also of the opinion that organisations should focus on continuously measuring their operational practices to determine current and longer term competitive success.

Lastly, bringing oneself more fully into one's work roles and devoting greater amounts of cognitive, emotional and physical resources is a very profound way for individuals to respond to an organisation's actions, as suggested earlier by the work of Kahn (1990). Employees are more likely to exchange their engagement for resources and benefits provided by their organisation and are therefore a talent management enabler. Ashton and Morton (2005, p. 11) state that 'talent management is integral to engaging employees in the organization.'

\section{Research design}

The framework that is used to define the processes of selecting the sources of information, the method of data collection and the technique of data analysis is commonly known as the research design (Silverman, 2018). This is explained below. An exploratory research design was employed in this study.

\section{Research approach}

In this research, a qualitative research approach was used. According to Mugenda and Mugenda (2003), qualitative research is the best approach to use if the researcher intends to purposefully explore, describe, explain and interpret the collected data within a specific context. To achieve this, the researchers adopted the recommendation of Mills, Bonner and Francis (2006) to implement a constructivist grounded theory approach to collect qualitative data with an explorative purpose.

According to Mills et al. (2006, pp. 447-464), 'the constructivist theory is a methodology that seeks to construct theory about issues of importance in peoples' lives.' This means that issues of importance to participants emerge from the stories that they tell about an area of interest that they have in common with the researcher. The constructivist theory allows the data collection, data analysis and theory to stand in reciprocal relationships with each other (Strauss \& Corbin, 1990). The researchers analysed the data by constant comparison, initially of data with data, progressing to comparisons between their interpretations, translated into codes and categories and more data (Strauss \& Corbin, 1990).

\section{Research strategy}

Semi-structured interviews were conducted. In the collection and analysis of data, the researchers ensured that data comparisons within and between the responses were executed by the theoretical framework of the subject under study. The collection and analysis of data were executed taking cognisance of the theoretical framework of the subject under study and through the directive of grounded theory. This enabled the researchers to pinpoint the core facts of the talent management situation at the Ministry of Justice in Namibia.

\section{Research method}

This study was carried out with consideration of the research setting and the research procedure, which resulted in access to all the expected information.

\section{Research setting}

This research was directly executed in liaison with the Directorate of Central Administration. The Directorate of Central Administration is mandated to provide various administrative support services to the rest of the Ministry of Justice and the Office of the Attorney General in terms of its strategic objective: 'To ensure an enabling environment and high-performance culture' (Ministry of Justice, 2017, p. 5). 
The Directorate of Central Administration spans across four divisions, namely, Division General and Auxiliary Services (Subdivision Auxiliary Services, Subdivision Human Resource Management, Subdivision Human Resource Development and Subdivision Ministerial Support Service), Division Finance and Budgeting, Division Information Technology and Division Development Plans and Fixed Asset Management (Ministry of Justice, 2017). The main activities of the Directorate of Central Administration encompass managerial oversight, strategic leadership and corporate services to ensure that other directorates are able to deliver their services and to integrate the functioning of the ministry as a whole. Such services are aimed at providing administrative support to ministerial programmes, ensuring proper financial management and facilitating equitable distribution and effective utilisation of resources, as well as capacity-building (Ministry of Justice, 2017).

\section{Research procedure}

Because of the security at the Ministry of Justice, a request for authorisation was used to access the setting. The research was executed in accordance with the premises' regulations, irrespective of the fact that the government has an open policy for access to information. An approval letter was obtained from the Permanent Secretary of the Ministry of Justice that enabled the researchers to obtain full access to all the target sources of information.

\section{Entrée and establishment of the researchers' roles}

The 10 respondents were proposed to the Ministry of Justice Permanent Secretary's for approval. The Director of Human Resources Management, as per the Permanent Secretary's instruction, informed all proposed respondents accordingly. Each individual was approached through an email request for an appointment. The research purpose and ethical parameters such as freedom to withdraw, protection of privacy and confidential information were explained to each interviewee. Each respondent signed an informed consent form. Issues of confidentiality and privacy were reiterated during the course of the interviews. Confidentiality was ensured by numbering each interviewee instead of using their names and privacy was ensured by conducting the interview in a secluded venue.

\section{Research participants and sampling methods}

In recognising the relationships between theory and data, purposive sampling was utilised, and semi-structured interviews were employed as data collection method. Mougeot (2006) defines sampling as the process of selecting a number of study units from a defined study population. Purposive sampling was the best tool to find answers to the research questions and was performed in this study according to criteria relevant to the research questions.

Accordingly, four top managers in the positions of senior managers, three assistant managers and three administrative officers were interviewed to gather the data and facts in relation to the execution of talent management in the Ministry of Justice. The targeted directors and their assistants were at managerial level, whereas the three administrative officers were from the HR department. The selection of these participants was based on the fact that they were of the few that were directly involved in talent management practices in this ministry. Saturation of data was reached after the 10th interview where no new information was obtained.

\section{Data collection methods}

In this study, semi-structured interviews were conducted to collect data. Piansoongnern and Anurit (2010) state that interviews enable the researcher to collect facts, gain an understanding of the respondents' opinions and experiences and establish the practical processes of the phenomenon under investigation. The information elicited through the interviews was compared or verified to enhance the credibility of the findings. This was performed by two researchers who coded the data and did the necessary comparisons.

\section{Recording of data}

The interviews were recorded digitally and corroborated by taking field notes. The data were stored on a recorder and transcribed on Word document to ensure that the quality of the data was not compromised.

When conducting qualitative research, ensuring trustworthiness of the data collected is of utmost importance. The term trustworthiness is used to represent data validity and data reliability. Its aim is to ensure that the study findings are collected and analysed with credibility. According to Maxwell (2011), five principles must be considered so as to ensure data validity, namely, credibility, transferability, dependability and conformability. The research was guided by the abovementioned principles; therefore, there is assurance that data trustworthiness was achieved. Credibility was ensured by ensuring that the interview questions were related to the purpose of the study. The findings of this study can be applied to other departments in the government department under study and is therefore transferable. To address dependability, the processes of data analysis were reported in detail, thereby enabling a future researcher to repeat the work, if not necessarily to gain the same results. The researchers ensured as far as possible that the research findings were the result of the experiences and ideas of the participants to address confirmability.

\section{Data analysis}

According to Strauss (1987):

Any researcher who wishes to become proficient at doing qualitative analysis must learn to code well and easily. The excellence of the research rests in large part on the excellence of the coding. (p. 27)

Qualitative content analysis was used to explore and analyse the information collected from the respondents and 
documents that were obtained as data sources. Content analysis was chosen because it is systematic, flexible and has the ability to reduce data into manageable categories and subcategories. This was achieved by examining every part of the interview transcript. Strauss (1987) further says that this method requires the researcher to be able to maintain focus on the phenomenon being investigated, guided by the respondents' meanings and the overall research question of the study. Qualitative data coding, through pre-set and emergent codes, was employed for organising and sorting data into manageable categories and subcategories. Deductive and inductive coding was used.

\section{Reporting}

From the interviews, main themes and categories were identified. For the purposes of anonymity, the research respondents were referred to as Respondent 1 up to Respondent 10 . The data will be presented with simplicity and clarity, as well as usability by future researchers. Verbatim or verbal quotes will be used to substantiate the categories. The quotes, in some instances, reflect a pool level of English as English is the second or even third language spoken by some of the respondents.

\section{Ethical considerations}

As extracted from Ritchie, Lewis, Nicholls and Ormston (2014), ethics refers to standards of conduct to which a particular group or profession is expected to conform. Ethical principles are also appropriate to the academic environment. According to Ritchie et al. (2014), it is required that students obtain ethical clearance from the institution at which they are registered before they carry out a research project.

This research complied with the code of ethics of the institution where it was conducted. A consent letter from the organisation under study was obtained. In addition, this study complied with privacy, confidentiality and anonymity requirements.

\section{Findings}

This section of the article reports on participants' responses about their views of talent management, as well as notes made during the interviews. The following themes were identified: HR execution, operational execution and strategic execution, which can be grouped as talent management execution levels. Human resource execution refers to the roles that HR needs to play in order to ensure that talent management is properly implemented. Operational execution entails the practical policies and procedures that need to be in place and strategic execution refers to the elements that relate the long-term aspects of talent management. These themes are discussed below under the sub-headings enablers and distractors. These distractors and enablers form part of the talent management practices.

\section{Theme 1: Human resource execution}

\section{Distractors}

The first category under theme 1 relates to the lack of proper implementation of performance management:

'We have no idea of any talent development programme in place but we have a performance management system introduced by the Office of the Prime Minister and still not fully implemented.' (Respondent 6, male, 58, chief training officer)

'There is a performance management system that requires supervisors to assess their teams' performance on a quarterly and annual basis which is still at early stage.' (Respondent 3, female, 46, chief legal drafter)

Performance management forms an integral part of talent management. It seems as if there is a performance management system at the Ministry of Justice, but it is not fully implemented. This distractor may cause future talent management initiatives to fail.

The second category links with performance management in the sense that there is lack of talent development:

'We don't have talent development.' (Respondent 7, female, 42 , senior human resources practitioner; Respondent 8 female, 36, human resources practitioner and Respondent 9, male, 46 , chief legal clerk)

'In our case is even worse due to the fact there is no talent development and lawyers need to continuously improve on their trial advocacy courses, which are worth millions of Rands that the Ministry cannot afford.' (Respondent 3, female, 46, chief legal drafters)

'We have a performance management system and there is no talent development.' (Respondent 1, female, 48, deputy director)

Talent development leads to the enhancement of highpotential employees with critical skills, such as the lawyers in the Ministry of Justice.

Lack of talent retention is the next category. This category was accentuated by most of the respondents, and it is therefore important to take notice of this category:

'There is nothing done here to identify talent and to retain.' (Respondent 7, female, 42, Senior Human Resources Practitioner)

'We don't have talent retention practices in the Ministry, talent acquisition we do through interviews.' (Respondent 6, male, 58, chief training officer)

'Most talented people always leave for better opportunities in private firms.' (Respondent 5 , female, 48 , permanent secretary)

According to most of the employees, talent retention was a major problem in the Ministry of Justice. A holistic approach will be necessary to develop a talent management plan because of the complexity thereof. Intrinsic and extrinsic motivation should be taken into consideration.

\section{Enablers}

Another category, talent acquisition, emerged in a positive light. This could be seen as an enabler:

'Well-constructed interviews enable us to get right candidates ...' (Respondent 6, male, 58, chief training officer) 
'Further put it like this: our acquisition is done through interviews.' (Respondent 7, female, 42, Senior Human Resources Practitioner)

The HR staff managed to identify talent and conduct wellconstructed interviews. This is a clear enabler in the talent management process.

\section{Theme 2: Operational execution}

\section{Distractors}

The first category under operational execution is remuneration challenges:

'Public service policy requires us to construct the job adverts in a way it attracts right people with right competencies and make them to want to work for the organisation and it made people to come with high expectations but in the end disappointed by the remuneration and other operational practices.' (Respondent 6, male, 58, chief training officer)

'Senior legislative drafters' positions are critical position that take eight to 10 years to be filled as there are few talented and experienced people out there willing to work for public services and this budget cut have a negatively impacted on the organisation.' (Respondent 2, senior human resources practitioner)

Remuneration challenges are evident on operational level and should therefore obtain the necessary attention.

Cumbersome rules and red tape of government were identified as the next category. The data suggested that respondents felt that public service rules had become an obstacle and needed to be revised as soon as possible:

'Our HR always co-ordinate with training committee and facilitate training programs, but with the Prime Minister' office (public service commission) being the primary approval authority, decision are not always in our favour. Public service commission keeps turning our talent management proposals down due to their cumbersome policies.' (Respondent 3, female, 46, Chief Legal Drafters)

'Public service rules cumbersomeness on recruitment policy causes a delay in recruitment and as a result we keep losing critical skilled and suitable candidate.' (Respondent 5, female, 48 , permanent secretary)

'The remuneration policy is also worrisome in today' competitive world, therefore I would like to leave you with a special request to assist the Namibian public service sectors implementing talent management, or otherwise the boat will completely be drowned.' (Respondent 6, male, 58, chief training officer)

'HR leaders always recommend candidates with strong and talent characters through the interviews, but the person might be discouraged by our remuneration policy which lacks reward and incentive packages.' (Respondent 5 , female, 48 , permanent secretary)

'I strongly believe that we suffer the impact of shortage of critical skills to implement an effective judiciary system and this shortage is a result of lack of talent management in the organisation mostly and by the public service recruitment rules.' (Respondent 3, female, 46, Chief Legal Drafters)
There is a clear link here between financial constraints, remuneration packages and policies, as discussed in the categories above. Without proper policies and rules, it is impossible to execute talent management effectively.

\section{Enablers}

No categories were identified. It is therefore clear that the operational execution in this organisation needs to be revisited to enable all stakeholders to win the war for talent. It is expected on an operational level that engagement be evident to ensure proper execution of talent management. The reason why no enabler was identified could be that there was no proper engagement to share with the interviewer.

\section{Theme 3: Strategic execution}

\section{Distractors}

The lack of leadership skills was a distractor at this organisation:

'Another challenge we have is lack of top leadership talent skills in the whole public service at large.' (Respondent 5 , female, 48 , permanent secretary)

'Our top managers lack talent leadership skills and as a result, it affects the whole organisation.' (Respondent 8, female, 36, human resources practitioner)

If leadership does not enable the staff to successfully execute their work and let the staff experience satisfaction in the workplace, they may resign.

\section{Enablers}

On a positive note, there was evidence of strategic planning, which can be grouped as an enabling factor:

'I do not know how it is incorporated in business strategy, but we have a five-year National Development Plan and Vision 2030.' (Respondent 3, female, 46, Chief Legal Drafters)

'I think Harambe Prosperity Plan, which is aimed at improving the public service, is one of those strategies.' (Respondent 5, female, 48 , permanent secretary)

It is imperative to note that there is a level of strategic thinking in the government sector in Namibia, which may assist the talent management process in the Ministry of Justice. Planning is essential and it seems like management in the Namibian public sector came to this realisation. A talent management strategy should therefore be linked to these strategic plans.

All the above themes and categories were summarised and illustrated in a conceptual framework in Figure 1. This framework was developed to summarise and illuminate talent management execution by focusing on the enabling and distracting factors in the Ministry of Justice in the Namibian public sector.

It is clear from Figure 1 that there were three talent management execution levels: HR execution, operational execution and strategic execution. Distractors and enablers 


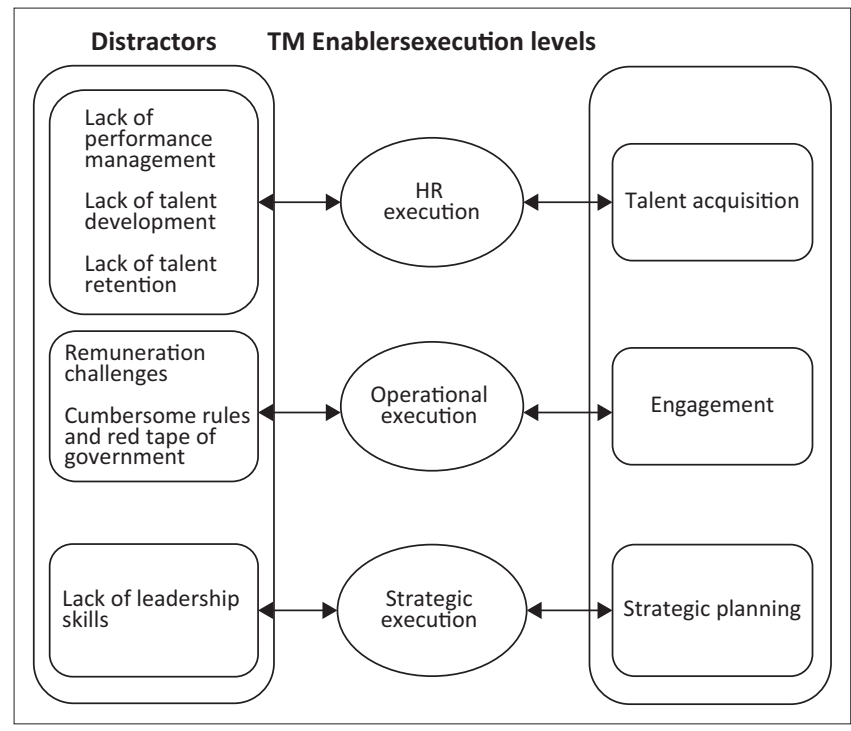

HR, Human Resource; TM, Talent Management.

FIGURE 1: Conceptual framework of talent management execution in the Ministry of Justice in the Namibian public sector.

were identified in each of these execution levels, except for operational matters where there was no enabler. These distractors and enablers formed part of the talent management practices in the Ministry of Justice. It is important to note that engagement was not found to be theme in findings, but should be part of this figure because of the essence thereof found in the literature review (Morton, 2005).

\section{Discussion}

The aim of this study was to scrutinise the execution of talent management practices in the Ministry of Justice in the Namibian public sector by identifying distracting and enabling factors. In the findings, the following talent management execution levels were identified: HR execution, operational execution and strategic execution. The lack of performance management and the lack of talent development and talent retention were grouped as the distractors at HR execution level. At operational execution level, remuneration challenges and cumbersome rules and red tape of government were identified. A lack of leadership was placed as a distractor at strategic execution level. Talent acquisition is an enabler at HR execution level. Engagement is an operational execution enabler. Lastly, strategic planning was positioned as an enabler at the strategic execution level. The relationship between HR execution, operational execution and strategic execution is essential in the sense that talent management cannot be executed in isolation. Human resource usually initiates the talent management processes and the execution thereof. At an operational level, engagement between HR, management and employees is essential to ensure proper execution. Leadership and strategic planning are key issues to effective strategic talent management execution.

The interviewees made no mention of engagement, which may be an indication of an authoritative environment with little interaction between management and staff.
Ideally, engagement should have been part of the conceptual framework in Figure 1, as seen in the literature review.

Talent development and talent retention were not reported to be practiced in the Ministry of Justice; therefore, the organisation's survival is at risk. This concurs with the findings of Kapoor (2011). In this study, continuous alignment of an organisation's business operational practices with talent management was found to be a strategic tool for future success and investors' attraction. Based on the findings of Hughes and Rog (2008), it appears that organisations could benefit from the increased integration of some HRM practices that fall clearly within the talent management domain, including retention, workforce planning, leadership and professional development, which agrees with findings of this study. When an organisation is operated without focusing on talent management practices, there will be no progress on the horizon (Tafti, Mahmoudsalehi, \& Amiri, 2017), which corresponds with the findings of this study. According to Johnson (2015), talent management practices are focal tools for attracting top talent to key roles. This view was reiterated by the findings of this study. It was clear that remuneration challenges as well as inadequate policies and rules were raised by most of the interviewees to be the most detrimental distractors. In concurrence with the findings of this study, the implementation of talent strategy is expected to drive value in the business and this is an enabler (Sparrow \& Makram, 2015).

In our view, talent management execution at the ministry under study still needs the necessary attention. The execution of talent management at HR, operational and strategic levels is not fully fletched. An observation that we made was that proper communication lacked between HR, management and the staff members. This could be a reason why engagement was not identified as an enabler. Performance management is a prominent aspect of talent management, but is overseen up to a certain extent at this ministry. The lack of talent development and talent retention at HR execution level are also serious concerns and HR therefore needs to improve their processes. At operational execution level, management needs to pay attention to remuneration challenges and reduce cumbersome rules and the red tape. This could be linked to the lack of leadership that was placed as a distractor at strategic execution level. Talent acquisition seems to shed light at the HR execution level and strategic planning at the strategic execution level.

\section{Practical implications}

This article scrutinised the status quo in the Ministry of Justice with regard to the application of talent management practices. The starting point should be linking talent management to the day-to-day operational practices of the organisation through the involvement of top managers. To execute talent management properly, managers and HR managers should deal with enablers and distractors related to talent management execution levels. It is imperative that the HR staff, management and operational staff should therefore be involved in the execution of talent management. Engagement on all three levels is essential. Talent management 
is important to ensure that organisations can successfully acquire and retain essential talent, as well to ensure that employees are engaged on all levels. According to Santhanam (2018), talent management challenges can be successfully addressed through managing a coaching programme that consists of key contributors such as organisational culture, business and employee demand, lifelong learning, a topdriven approach, a high success rate and employee sourcing and retention. The ability to effectively address both of these issues has become a primary determinant of organisational success and, in some cases, even survival. As shown in Figure 1, there were six distractors and three enablers. The implication of this can therefore be presumed to be that the execution of talent management in this Ministry is not successful.

\section{Recommendations}

Performance management in this ministry is not yet established and therefore in an early stage. However, performance management forms an integral part of talent management. Top management must support this system to ensure that talent management initiatives can succeed. A talent retention strategy should be developed to ensure that staff members, such as lawyers, stay with the Ministry of Justice. A holistic approach is needed to compile such a strategy, and this may include benchmarking and engaging with management, identified talent as well as HR and operational staff. Other problems such as organisational culture and low motivation may affect the retention of staff within the ministry and should therefore be investigated. The policies and rules should be revisited to accommodate successful execution of talent management in the ministry. Operational matters, specifically enabling factors, in this organisation need to be revisited to win the war for talent. Leadership skills training is necessary, especially for top management in the Ministry of Justice. It is recommended that the Ministry pays attention to the distractors identified in this study and builds on the enablers. Engagement on all levels is an essential part of talent management and should be developed into an enabler in the talent management process. A talent management strategy should be linked to the strategic plans of the Namibian public sector.

Future research might consist of similar qualitative studies that can be conducted in other departments of the Namibian government and the private sector in Namibia. A quantitative study on talent management in the whole Namibian government should be conducted to detect the impact of talent management on staff and management as well as on productivity and service delivery. The conceptual framework of talent management execution levels in the Ministry of Justice in the Namibian public sector should be compared with other government departments in Namibia to detect holistic enablers and distractors to enhance talent management. Further studies are needed to build on the conceptual framework of talent management execution because of the dynamics that evolve around HR, operational and strategic challenges and in order to prepare for the future world of work.

\section{Conclusion}

The purpose of this study was met by exploring the execution of talent management in the Ministry of Justice in the Namibian public sector. Human resource execution, operational execution and strategic execution formed the talent management execution levels that were evident in this ministry. The lack of performance management, lack of talent development, lack of talent retention, remuneration challenges, cumbersome rules and red tape of government and lack of leadership were grouped as distractors, while talent acquisition, engagement and strategic planning were identified as enablers in talent management. These distractors and enablers formed part of the talent management practices in the Ministry of Justice in Namibia. A conceptual framework of talent management was developed to illustrate the three execution levels as well as the distractors and the enablers. Should the ministry continue with the current talent management system, it will hardly survive in this competitive world and keep on losing the war for talent. If the Ministry of Justice does not enhance the identified enablers and does not pay the necessary attention to the distractors, it could lead to redundancy of this unit. It is therefore of utmost importance for the Ministry of Justice to pay attention to the identified distractors as well as engagement that was not apparent as a talent management practice. Business leaders who execute the best talent management processes at HR, operational and strategic levels are more prepared than their competitors to compete in the global economy and capitalise quickly on new opportunities.

\section{Acknowledgements}

The authors would like to thank the staff members from various government ministries for providing relevant information throughout this research.

\section{Competing interests}

The authors declare that they have no financial or personal relationships that may have inappropriately influenced them in writing this article.

\section{Authors' contributions}

This study was conducted by K.F. as part of his master's thesis at the Southern Business School. C.M.S. was the supervisor and co-wrote the article.

\section{Funding information}

This research received no specific grant from any funding agency in the public, commercial or not-for-profit sectors.

\section{Data availibility statement}

Data sharing is not applicable to this article as no new data were created or analysed in this study. 


\section{Disclaimer}

The views and opinions expressed in this article are those of the authors and do not necessarily reflect the official policy or position of any affiliated agency of the authors.

\section{References}

Ashton, C., \& Morton, L. (2005). Managing talent for competitive advantage: Taking a systemic approach to talent management. Strategic HR Review, 4(5), 28-31. https://doi.org/10.1108/14754390580000819

Barkhuizen, N., Schutte, N., \& Smit, A. (2015). Talent management, motivation and service quality of support staff in a public higher education institution. Journal of Public Administration, 50(special issue 1), 658-673.

Bothma, R. (2015). Implement a comprehensive talent management solution. HR Future, 11(1), 34-35.

Craig, D. (2017). Catalyst consulting. HR Future, September, 24-26.

Dinnen, M. (2017). How to hire exceptional talent. HR Future, June, 10-11.

Hosking, A. (2017). Make pre-hire talent assessments a part of your predictive talent acquisition strategy. HR Future, February, 10-13.

Hughes, J.C., \& Rog, E. (2008). Talent management. International Journal of Contemporary Hospitality Management, 20(7), 743-757. https://doi.org/ 10.1108/09596110810899086

Johnson, C. (2015). New frontiers in talent management. HR Future, 6(1), 28-30.

Kahn, W.A. (1990) Psychological conditions of personal engagement and disengagement at work. Academy of Management Journal, 33, 692-724. https://doi.org/10.5465/ 256287

Kapoor, R. (2011). Collaborative innovation in the global semiconductor industry. A report on the findings from the 2010 Wharton-GSA Semiconductor Ecosystem Survey, Global Semiconductor Alliance, Pennsylvania. Retrieved January 15 Survey, Global Semiconductor Alliance, Pennsylvania. Retrieved January 15,
2019, from https://faculty.wharton.upenn.edu/wp-content/uploads/2012/05/ 2019, from https://faculty.wharton.up
SemiconductorEcosystemStudyFinal.pdf.

King, K.A. (2017). The talent climate: Creating an organisational context supportive of sustainable talent development through implementation of a strong talent
system. Journal of Organizational Effectiveness: People and Performance, 4(4), 298-314. https://doi.org/10.1108/JOEPP-03-2017-0023

Krasavin, A., \& De Swardt, D. (2016). Enhance your employee experience. HR Future, October, 34-35.

Lee, G. J. (2018). Talent measurement: A holistic model and routes forward. SA Journa of Human Resource Management, 16, a990. https://doi.org/10.4102/sajhrm. v16i0.990

Lewis, R. E., \& Heckman, R. J. (2006). Talent management: A critical review. Human Resources Management Review, 16, 139-154. https://doi.org/10.1016/j.hrmr. 2006.03.001

Li, J., Hedayati-Mehdiabadi, A., Choi, J., Wu, F., \& Bell, A. (2018). Talent management process in Asia: A multiple case study. European Journal of Training and Development, 42(7/8), 499-516. https://doi.org/10.1108/EJTD-04-2018-0035

Maheshwari, V., Gunesh, P., Lodorfos, G., \& Konstantopoulou, K. (2017). Exploring HR practitioners' perspective on employer branding and its role in organisational attractiveness and talent management. International Journal of Organizational Analysis, 25(5), 742-761. https://doi.org/10.1108/IJOA-03-2017-1136

Maxwell, J.A. (2011). Qualitative research design. London: Sage.

Mills, J., Bonner, A., \& Francis, K. (2006). The development of constructivist grounded theory International Journal of Qualitative Methods, 5(1), 1-10. https://doi.org/ $10.1177 / 160940690600500103$
Ministry of Justice. (2017). Annual report and accounts 2016-17. London: Ministry of Justice.

Mougeot, L. (2006). Growing better cities: Urban agriculture for sustainable development. Ottawa: International Development Research Centre.

Mugenda, O.M., \& Mugenda, A.G. (2003). Research methods: Quantitative and qualitative approaches. Nairobi: African Centre for Technology Studies.

Nakuta, J., \& Chipepera, F. (2010). The justice sector \& rule of law in Namibia. Windhoek: Meinert.

Ogbari, M.E., Onasanya, Y.A., Ogunnaike, O.O., \& Kehinde, O.J. (2018). Talent management as a determinant of firm performance: A conceptual approach. management as a determinant of firm perform
Business \& Social Sciences Journal, 3(1), 21-32

Pannell, M. (2015). (Real) talent is scarce, elusive, mobile and expensive. HR Future, $6(1), 26-27$.

Phillips, D.R., \& Roper, K.O. 2009. A framework for talent management in real estate. Journal of Corporate Real Estate, 11(1), 7-16. https://doi.org/10.1108/ 14630010910940525

Piansoongnern, O., \& Anurit, P. (2010). Talent management: Quantitative and qualitative studies of HR practitioners in Thailand. International Journal of Organizational Innovation, 3(1), 280-302.

Poisat, P., Mey, M.R., \& Sharp, G. (2018). Do talent management strategies influence the psychological contract within a diverse environment? SA Journal of Human Resource Management, 16(1), a1044. https://doi.org/10.4102/sajhrm. v16i0.1044

Riccardi, E. (2015). Attracting and retaining talent in the digital economy. HR Future, 4(1), 33.

Ritchie, J., Lewis, J, Nicholls, C.M. \& Ormston, R. (2014). Qualitative research practice: A guide for social science students and researchers. New Delhi: Sage.

Ross, S. (2013). Talent derailment: A multi-dimensional perspective for understanding talent. Industrial and Commercial Training, 45(1), 12-17. https://doi.org/10.1108/ 00197851311296656

Santhanam, P. (2018). Champion a coaching culture in your organisation. HR Future, October, 22-23.

Silverman, D. (2018). Doing qualitative research: A practical handbook. London: Sage.

Sirin, C. (2018). Adopt recruitment marketing and remain relevant. HR Future, June, 34-37.

Sparrow, P.R., \& Makram, H. (2015). What is the value of talent management? Building value-driven processes within a talent management architecture. Human Resource Management Review, 25(3), 249-263. https://doi.org/10.1016/jhrmr. Resource Manag
2015.04.002

Strauss, A.L. (1987). Qualitative analysis for social scientists. Cambridge: Cambridge University Press.

Strauss, A.L., \& Corbin, J.M. (1990). Basics of qualitative research: Grounded theory procedures and techniques. Los Angeles, CA: Sage.

Tansley, C. (2011). What do we mean by the term 'talent' in talent management? Industrial and Commercial Training, 43(5), 266-274. https://doi.org/10.1108/ 00197851111145853

Tafti, M.M., Mahmoudsalehi, M., \& Amiri, M. (2017). Critical success factors, challenges and obstacles in talent management. Indian Commercial Training, 49(1), 15-21. https://doi.org/10.1108/ICT-05-2016-0036

Ulrich, D. (2016). Win the war for talent through an investor focus. HR Future, October, 16-19.

Van Hoek, L. (2016). Millennial engineers: Talent management expectations and needs in an African mining corporation. Journal of Contemporary Management, 13(1), 482-505.

Van Zyl, E.S., Mathafena, R.B., \& Ras, J. (2017). The development of a talent management framework for the private sector. SA Journal of Human Resource Management, 15, a820. https://doi.org/10.4102/sajhrm.v15i0.820 